R. H. Holm, Inorg. Chim. Acta, 104, 33 (1985). - (4) U. Muller, P. Klingelhoffer, C. Friebel and J. Pebler, Angew. Chem. Int. Edit., 24, 689 (1985). - ${ }^{(5)}$ D. Fenske, B. Czeska, C. Schumacher, R. E. Schmidt and K. Dehnicke, Z. Anorg. Chem., 520, 7 (1985). - ${ }^{(6)}$ M. Draganjac and M. Rauchfuss, Angew. Chem. Int. Edit., 24, 742 (1985). - ${ }^{(7)}$ T. C. Mak, K. S. Jasim and C. Chieh, Inorg. Chem., 24, 1587 (1985). ${ }^{(8)}$ D. Fenske, J. Hachgenei and J. Ohmer, Angew. Chem. Int. Edit., 24, 706 (1985). - ${ }^{(9)}$ M. G. Kanatzidis, D. Coucouvanis, A. Simopoulos, A. Kostikas and V. Papaefthymiou, J. Am. Chem. Soc., 107, 4925 (1985). - ${ }^{(10)}$ W. E. Cleland and B. A. Averill, Inorg. Chim. Acta, 107, 187 (1985).

(11) D. Coucouvanis and M. G. Kanatzidis, J. Am. Chem. Soc., 107, 5005 (1985). - ${ }^{(12)}$ H. Brunner, N. Janietz, J. Wachter, T. Zahn and M. I. Zielger, Angew. Chem. Int. Edit., 24, 133 (1985). - ${ }^{(13)}$ T. R. Halbert, S. A. Cohen and E. I. Stiefel, Organometallics, 4, 1689 (1985). - ${ }^{(14)}$ A. D. Watson, Ch. Pulla-Rao, J. R. Dorfman and R. H. Holm, Inorg. Chem., 24, 2820 (1985). - ${ }^{(15)}$ G. Henkel, K. Grieve and B. Krebs, Angew. Chem. Int. Edit. 24, 117 (1985). - ${ }^{(16)}$ J. K. Morley, J. C. Huffman and G. Christou, Inorg. Chem., 24, 3297 (1985). (17) J. W. McDonald, Inorg. Chem., 24, 1734 (1985). - ${ }^{(18)}$ P. Legzdins and L. Sanchez, J. Am. Chem. Soc., 107, $5525(1985) .-{ }^{(19)} \mathrm{E}$. Roland, E. C. Walborsky, J. C. Dewan and R. R. Schrock, J. Am.
Chem. Soc., 107, 5795 (1985). - ${ }^{(20)}$ H. Schäfter, D. Binder and D. Fenske, Angew. Chem. Int. Edit., 24, 522 (1985).

(21) O. J. Scherer, H. Sitzmann, G. Wolmerhauser, Angew. Chem. Int. Edit., 24, 357 (1985). - ${ }^{(22)}$ L. B. Kool, M. D. Rausch, H. G. Alt, M. Herberhold, U. Thewalt and B. Wolf, Angew. Chem. Int. Edit., 24, 394 (1985). - ${ }^{(23)}$ M. Bookhart, K. Cox, F. G. N. Cloke, J. C. Green, M. L. H. Green, P. M. Hare, J. Bashbin, A. E. Derome and P. D. Grebenik, J. Chem. Soc., Dalton Trans., 423 (1985). - ${ }^{(24)}$ D. Lyons and G. Wilkinson, J. Chem. Soc., Dalton Trans., 587 (1985), - ${ }^{(25)}$ G. S. Gerolami, G. Wilkinson, A. M. R. Galas, M. Thornton-Pett, $J$. Chem. Soc., Dalton Trans., 1339 (1985). - ${ }^{(26)}$ J. E. Salt, C. G. Girolami, G. Wilkinson, M. Motevalli, M. Thornton-Pett, M. B. Hursthouse, J. Chem. Soc., Dalton Trans., $685(1985) .-{ }^{(27)}$ G. S. Girolani, C. G. Howard, G. Wilkinson, H. M. Dawes, M. Thornton-Pett, M. Motevalli, M. B. Hursthouse, J. Chem. Soc., Dalton Trans., 921 (1985). - ${ }^{(28)}$ J. A. Iggo and B. L. Shaw, J. Chem. Soc., Dalton Trans., 1009 (1985). - (29) G. S. White and D. W. Stephen, Inorg. Chem., 24, 1499 (1985). - ${ }^{(30)}$ G. S. Ferguson and P. T. Wolczanski, Organometallics, 4, 1601 (1985).

${ }^{(31)}$ S. J. Young, H. Hope and N. E. Schore, Organometallics, 3, 1585 (1985).

J. R. Dilworth

\title{
Additions and Corrections
}

\author{
Synthesis of $\left[\mathrm{SCo}_{3}(\mathrm{CO})_{7}\left(\mathrm{~S}_{2} \mathrm{COMe}\right)\right]$ and the Structure of its \\ $\mathbf{P P h}_{3}$ Derivative
}

L. Markó, G. Gervasio, P. L. Stanghellini and G. Bor: Transition Met. Chem., 10, 344 (1985)

Pages 345 and 347: The spectrum shown in Figure 2 is taken in CsI disk and the spectrum shown in Figure 4 is taken in $\mathrm{n}$-heptane, not vice versa and given in the existing captions.

\footnotetext{
(C) VCH Verlagsgesellschaft mbH, D-6940 Weinheim, 1986. - Printed in the Federal Republic of Germany by Schwetzinger Verlagsdruckerei GmbH, D-6830 Schwetzingen. - All rights reserved (including those of translations into foreign languages). Subscription price: DM 660,00, single issues: DM 64,00, plus postage and handling charges. Editor-in-Chief: Dr. D. R. M. Walton, Univ. of Sussex, School of Chemistry and Molecular Sciences, Brighton BN1 9QJ, England; Advertising Manager: R. J. Roth, D-6940 Weinheim; Published by VCH Verlagsgesellschaft $\mathrm{mbH}$, (Managing Directors: Prof. Dr. Helmut Grünewald and Hans Dirk Köhler), Pappelallee 3, P. O. Box 12 60/12 80, D-6940 Weinheim, Federal Republic of Germany. Transition Metal Chemistry does not publish book reviews; books submitted for review will not be returned. Valid for users in the USA: The appearance of the code at the bottom of the first page of an article in this journal (serial) indicates the copyright owner's consent that copies of the article may be made for personal or internal use, or for the personal or internal use of specific clients. This consent is given on the condition, however, that the copier pay the stated percopy fee through the Copyright Clearance Center, Inc., for copying beyond that permitted by Sections 107 or 108 of the U.S. Copyright Law. This consent does not extend to other kinds of copying, such as copying for general distribution, for advertising or promotional purpose, for creating new collective work, or for resale. For copying from back volumes of this journal see "Permissions to Photo-Copy: Publisher's Fee List" of the CCC.
} 